\title{
Perillyl Alcohol
}

National Cancer Institute

\section{Source}

National Cancer Institute. Perillyl Alcohol. NCI Thesaurus. Code C1461.

A naturally occurring monoterpene related to limonene with antineoplastic activity. Perillyl alcohol inhibits farnesyl transferase and geranylgeranyl transferase, thereby preventing post-translational protein farnesylation and isoprenylation and activation of oncoproteins such as p21-ras, and arresting tumor cells in the G1 phase of the cell cycle. ( $\mathrm{NCl04}$ ) 